Original

\title{
PEG-rHuMGDF Causes Osteogenesis by Stimulating Osteoblast Differentiation and Inhibiting Osteoclast Differentiation in Normal Mice
}

\author{
Youichi Ide ${ }^{1}$, Eri Yamanaka ${ }^{1}$, Yasuko Namiki ${ }^{1}$, Yasuko Kikuchi ${ }^{1}$, Hiromi Ishii ${ }^{1}$, \\ Jun-ichi Kawahara ${ }^{1}$, and Kunio Doi ${ }^{2}$ \\ ${ }^{1}$ Pharmaceutical Development Laboratory, Kirin Brewery Co., Ltd., Gunma 371-0853, Japan \\ ${ }^{2}$ Department of Veterinary Pathology, Faculty of Agriculture, The University of Tokyo, Tokyo 113-8657, Japan
}

\begin{abstract}
We studied the time courses of the number of osteoclasts, the expression of osteoblast differentiation markers and TGF- $\beta 1$ levels in the platelet-poor plasma (PPP) in order to clarify the mechanism of pegylated recombinant human megakaryocyte growth and development factor (PEG-rHuMGDF)-induced bone formation in the mouse. Mice received PEG-rHuMGDF subcutaneously at a suprapharmacological dose $(1.0 \mathrm{mg} / \mathrm{kg}$ ) daily for 5 days (Day of the first injection: Day 1). PEG-rHuMGDF caused a gradual increase of platelet count, with a maximum increase on day 9 . Histological analysis showed an increase of reticulin fibers on the inner side of endosteum on day 9, partial osteoid formation on day 11, new and excessive bone formation on day 13. On day 9, at the early stage of reticulin fiber increase, the number of osteoclasts was decreased. On day 11, osteopontin (OPN) mRNA-expression, a marker of osteoblast production, was observed in the reticulin fiber and osteoid near the substantia of bone marrow, whereas OPN mRNA-expressing cells did not express bone Gla protein (BGP) mRNA, a marker of osteoblasts, indicating that the expression of OPN mRNA was induced earlier than that of BGP mRNA during the course of osteogenesis. Additionally, the level of TGF- $\beta 1$ in the PPP was increased, with about 2.5-fold elevation compared with the vehicle-treated mice at day 9 . These findings suggest that PEG-rHuMGDF causes increase of reticulin fibers and osteogenesis by stimulating osteoblast differentiation and inhibiting osteoclast differentiation via an increase of the TGF- $\beta 1$ level in the bone marrow. ( $\mathrm{J}$ Toxicol Pathol 2001; 14: 113-120)
\end{abstract}

Key words: osteoclast, osteoblast, bone marrow, megakaryocyte, TGF- $\beta 1$

\section{Introduction}

Pegylated recombinant human megakaryocyte growth and development factor (PEG-rHuMGDF) is a recombinant pegylated truncated c-Mpl ligand ${ }^{1-4}$. PEG-rHuMGDF has been reported to cause an increase of the circulating platelet count in normal mice, normal rats, and rhesus monkey ${ }^{1,5-7}$ and be effective on some experimental animal models of thrombocytopenia ${ }^{8-12}$. Therefore, PEG-rHuMGDF is expected to be effective on some clinical thrombocytopenia. However, the suprapharmacological dose of PEGrHuMGDF is also reported to cause reversible bone formation following myelofibrosis in normal rats and PEGrHuMGDF-overexpressing mice , $^{13-15}$.

The maintenance of bone mass is determined by a

Received: 13 December 2000, Accepted 12 March 2001

Mailing address: Youichi Ide, Pharmaceutical Development

Laboratory, Kirin Brewery Co., Ltd., 2-2 Souja-machi 1 chome,

Maebashi-shi, Gunma 371-0853, Japan

TEL: 81-27-254-8609 FAX81-27-254-5145

E-mail: y-ide@kirin.co.jp balance of the rates between bone formation and bone resorption. In regard to bone formation, it is generally considered that osteoblasts are differentiated from precursor cells derived from preosteoblasts, which are in turn derived from undifferentiated mesenchymal cells ${ }^{16-18}$. On the other hand, osteoclasts function in bone resorption in the bone marrow, and are differentiated through monocyte-lineage from hematopoietic stem cells.

Several investigators have hypothesized that growth factors derived from megakaryocytes, such as transforming growth factor- $\beta 1$ (TGF- $\beta 1$ ) and platelet-derived growth factor (PDGF), are responsible for the pathogenesis of idiopathic myelofibrosis ${ }^{19-21}$. In our previous study, PEGrHuMGDF caused a marked increase of the TGF- $\beta 1$ level in the bone marrow in association with the induction of myelofibrosis in the normal rats ${ }^{5}$. Several in vivo studies have demonstrated that TGF- $\beta 1$ promotes an increase of proliferation of periosteal osteoblast precursor cells and formation of new woven bone ${ }^{22}$. And, recent reports have demonstrated that PEG-rHuMGDF caused inhibition of osteoclastogenesis via the induction of TGF- $\beta 1$ and PDGF in vitro $^{23}$. 
In this study, we tried to clear the mechanism of bone formation in PEG-rHuMGDF-treated mice. We presumed that PEG-rHuMGDF changes the balance of the rate between bone formation and resorption by inducing the increase of TGF- $\beta 1$ levels in the bone marrow. Therefore, we examined the number of osteoclasts and the gene expression of osteoblast differentiation markers in the mice during PEG-rHuMGDF-induced bone development. In addition, we also measured the TGF- $\beta 1$ levels in the plasma to determine whether TGF- $\beta 1$ derived from megakaryocytes might play an important role in the bone marrow.

\section{Materials and Methods}

\section{$M G D F$ reagents}

rHuMGDF was expressed in E.coli, purified to homogeneity and derivitized with polyethylene glycol. PEG-rHuMGDF was produced in our laboratory and AMGEN Inc (Thousand Oaks, CA).

\section{Animal}

Male BALB/c mice were used in this study. They had access to food and water ad libitum, and were housed in a barriered room at the Kirin Vivarium under pathogen-free conditions (room temperature, $20-25^{\circ} \mathrm{C}$; relative humidity, 40-70\%; air changes, 10-15 times/hour; 12 h-light/12-dark cycle). This study was conducted in accordance with the Animal Welfare Guidelines in Japan and the Index of Experiments with Animals in the Kirin Brewery Co., Ltd.

\section{Platelet counts}

About ten-week-old male mice $(n=60)$ weighing approximately 26-30 g (Charles River Japan, Tsukuba, Japan) were used. The mice were divided into two groups $(\mathrm{n}=30$ each) and PEG-rHuMGDF at a dose of $1.0 \mathrm{mg} / \mathrm{kg}$ or vehicle was subcutaneously administered daily for 5 days (Day of the first injection: day 1$)$. The mice $(n=5)$ were then killed on days $1,7,9,11,13$, and 15 after the first injection. Each mouse was anesthetized with ether and peripheral blood was collected from the posterior vena cava.

The blood obtained was transferred into a blood collection tube containing EDTA-2K. The blood was diluted with Cellpack diluent (Toa Medical Electronics, Kobe, Japan) according to the increase in the platelet count. The peripheral platelet count was determined with a Sysmex cell counter (E-2000, Toa).

The dose and duration of PEG-rHuMGDF treatment to the mice were determined according to the results of our preliminary study. PEG-rHuMGDF caused a significant increase of platelet count in normal mice at a dose of $1 \mu \mathrm{g} / \mathrm{kg}$ without inducing bone formation ${ }^{11}$. In the present study, PEG-rHuMGDF at a suprapharmacological dose $(1.0 \mathrm{mg}$ / $\mathrm{kg}$ ) was administered to induce bone formation in the bone marrow.

\section{TGF- $\beta 1$ determination}

About nine-week-old male mice $(n=50)$ weighing approximately 24-28 g (Charles River Japan, Tsukuba, Japan) were used. The mice were divided into two groups $(\mathrm{n}=25 \mathrm{each})$, and PEG-rHuMGDF at a dose of $1.0 \mathrm{mg} / \mathrm{kg}$ or vehicle was subcutaneously administered daily for 5 days (day of the first injection: day 1$)$. The mice $(n=5)$ were then killed on days 7, 9, 11, 13, and 15 after the first injection. Each mouse was anesthetized with ether and peripheral blood was collected from the posterior vena cava

Platelet-poor plasma (PPP) was prepared as described elsewhere ${ }^{24-25}$. Briefly, plasma was prepared from whole blood anticoagulated with heparin-Na by centrifugation at $1,000 \mathrm{~g}$ for $30 \mathrm{~min}$. PPP was then obtained from the plasma by centrifugation at $10,000 \mathrm{~g}$ for $10 \mathrm{~min}$.

Latent TGF- $\beta 1$ in the samples was activated to an immunoreactive form by acetic acid/urea treatment and TGF- $\beta 1$ levels were then measured. The TGF- $\beta 1$ levels in the PPP were measured by an immunoassay using a human TGF- $\beta 1$ immunoassay kit (Genzyme, Basel, Switzerland) as described elsewhere ${ }^{26}$.

\section{In situ hybridization \& histology}

Animals: About ten-week-old male mice $(\mathrm{n}=25)$ weighing approximately 24-26 g (Charles River Japan, Tsukuba, Japan) were used. The mice were divided into two groups (PEG-rHuMGDF-group and non-treated-group). The mice of PEG-rHuMGDF-group $(n=20)$ received PEGrHuMGDF injection at a dose of $1.0 \mathrm{mg} / \mathrm{kg}$ subcutaneously daily for 5 days (Day of the first injection: day 1) and were then killed on days 9, 11, 13, and 15 after the first injection (each day: $n=5)$. The mice of non-treated-group $(n=5)$ were not administered any injection and were killed on day 15 . Each mouse was anesthetized with ether and fixed by perfusion with $4 \%$ paraformaldehyde/ $0.5 \%$ glutaraldehyde solution in phosphate buffer.

Tissue sections: After fixation, the femurs were decalcified by treatment with $10 \%$ EDTA for 5 days. They were then embedded in paraffin and cut to prepare $1 \mu \mathrm{m}$ longitudinal sections. These sections were then transferred to poly-L-lysine-coated glass slides, deparaffinized, and further treated for histological and in situ hybridization analyses as described below.

Histological analysis and quantification of osteoclasts: Sections were stained with hematoxylin and eosin and by Watanabe's silver stain method. Tartaric acid resistant acid phosphatase (TRAP) staining was performed to identify osteoclasts. The cells showing a positive reaction to TRAP staining were considered to be osteoclasts. For the quantitative evaluation of osteoclasts, TRAP-positive cell counts were measured in a $5.2 \mathrm{~mm}^{2}$ area of the epiphysis in the bone marrow using the morphometric analysis system Mac Scope (MITANI CORPORATION, Fukui, Japan).

RNA probes: Both antisense and sense (control) digoxigenin-11-UTP-labeled single-stranded RNA probes were prepared using a DIG RNA labeling kit (Boehringer Mannheim GmbH Biochemica, Mannheim, Germany) according to the manufacture's instruction. For generation of the mouse osteopontin probe, a 591-bp fragment of OPN 
cDNA obtained by RT-PCR was subcloned into pUC plasmid. The plasmid was either linearized with HindIII and transcribed with T7 RNA polymerase to generate a 591-bplong antisense (cRNA) probe, or linearized with Bam HI and transcribed with SP6 RNA polymerase to generate a sense probe.

In situ hybridization: The in situ hybridization technique has been described previously ${ }^{27}$. Hybridization of OPN and BGP mRNAs was performed at $50^{\circ} \mathrm{C}$ for 16 hours using digoxigenin-UTP-labeled RNA probes, and the signals were detected by NBT and BCIP. For controls, hybridization was performed with the sense probes. The control hybridizations showed no detectable signals.

\section{Statistical analysis}

The results are presented as mean \pm standard deviation (SD). The data was analyzed with the two-tailed student's $t$-test.

\section{Results}

\section{Platelet counts}

The treatment of PEG-rHuMGDF at a dose of $1.0 \mathrm{mg} /$ $\mathrm{kg}$ caused a gradual increase of platelet counts by about 5 times compared with the vehicle-treated mice at day 9. Platelet count of PEG-rHuMGDF-treated mice was still higher than that of vehicle-treated mice at day 15 (Fig. 1).

\section{TGF- $\beta 1$ levels in the PPP}

Treatment with PEG-rHuMGDF transiently increased the levels of TGF- $\beta 1$ in the PPP with a peak elevation of about 2.5 -fold compared with the level in the vehicle-treated mice at day 9. TGF- $\beta 1$ levels of PEG-rHuMGDF-treated mice began to decrease from day 11 , and reached control levels at day 15 (Fig. 2).

\section{In situ hybridization \& histology}

Histological changes: In PEG-rHuMGDF-treated mice, an increase of reticulin fibers on the inner side of the endosteum and megakaryocyte hyperplasia were observed on day 9. Reticulin fibers were expanded between substantia, and partial osteoid formation was seen along substantia on day 11 when megakaryocyte hyperplasia was not seen. New and excessive bone formation was seen on day 13, and this new and excessive bone began to be absorbed starting on day 15 (Fig. 3) (Table 1).

Osteoclast numbers in the bone marrow: TRAP staining showed that PEG-rHuMGDF caused a decrease of the number of TRAP-positive cells on day 9 compared with non-treated mice. On the other hand, the number of TRAPpositive cells in the PEG-rHuMGDF-treated mice was greater than that in the non-treated mice on day 15, when the new and excessive bone began to be absorbed (Fig. 4).

Expression of bone differentiation markers: On day 9 , at the early stage of reticulin fiber increase, osteoblasts at the endosteum (lining osteoblasts) expressed OPN mRNA and BGP mRNA. On the other hand, the cells involved in

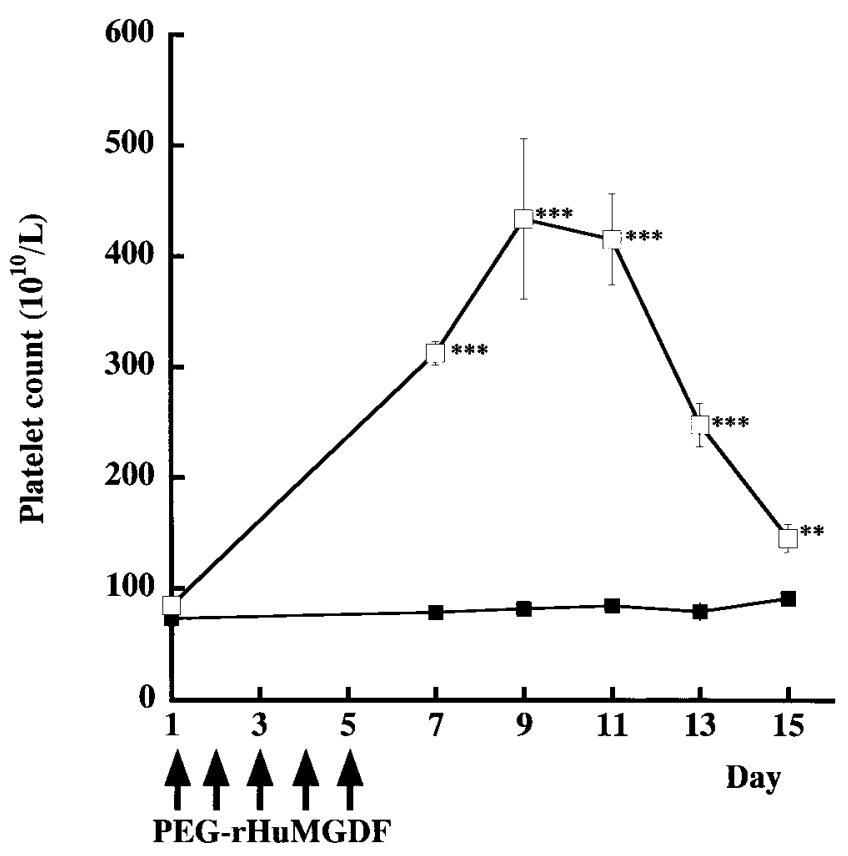

Fig. 1. Effect of PEG-rHuMGDF on the number of platelets in mice. Each point represents the mean $\pm S D(n=5)$. Data were analyzed by the two-tailed Student's $t$-test. ** $\mathrm{P}<0.01$, *** $\mathrm{P}<0.001$ compared with vehicle-treated.

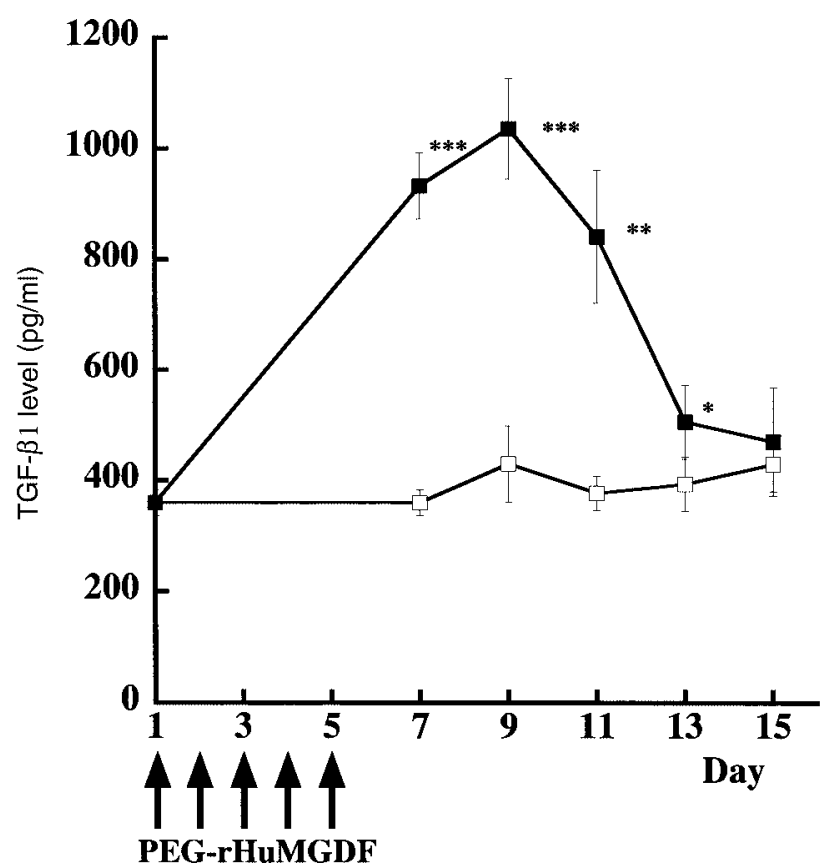

Fig. 2. Time course change of the TGF- $\beta 1$ level in the platelet-poor plasma. Each point represents the mean $\pm \mathrm{SD}(\mathrm{n}=5)$. Data were analyzed by the two-tailed Student's $t$-test. * $\mathrm{P}<0.05$, ** $\mathrm{P}<0.01$, *** $\mathrm{P}<0.001$ compared with vehicle-treated. 
A

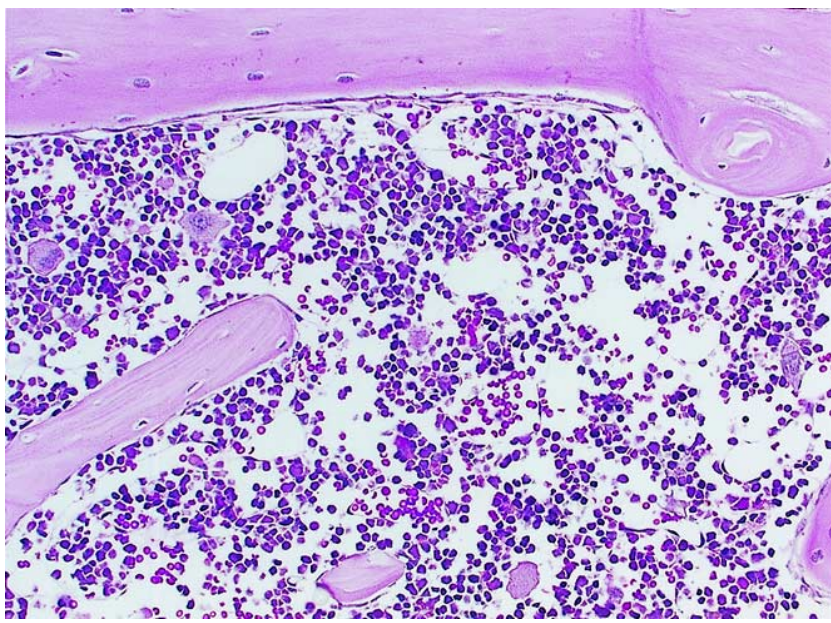

B

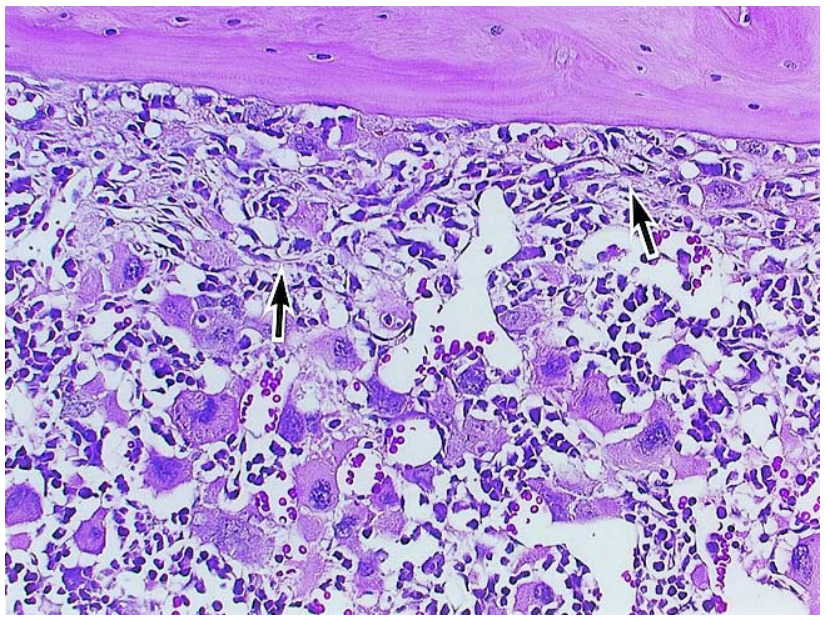

C

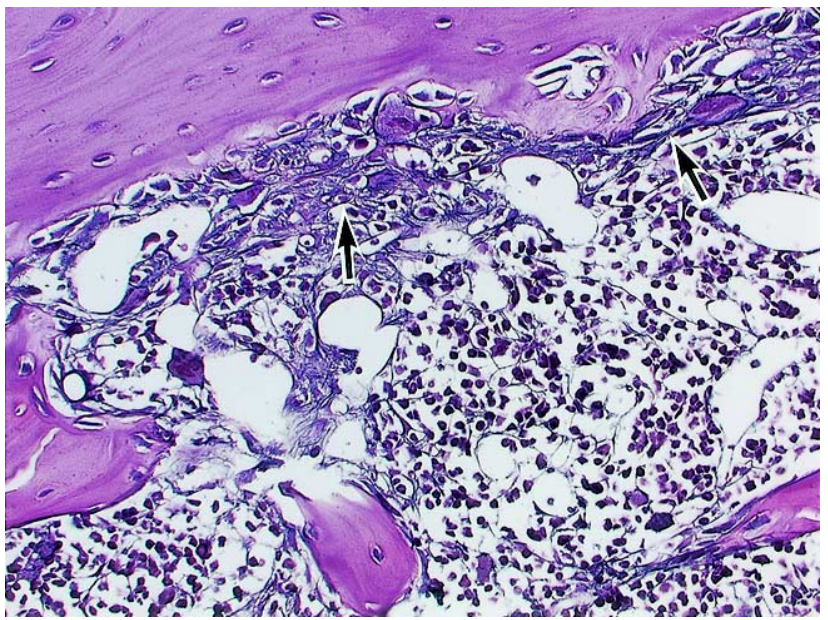

\section{D}

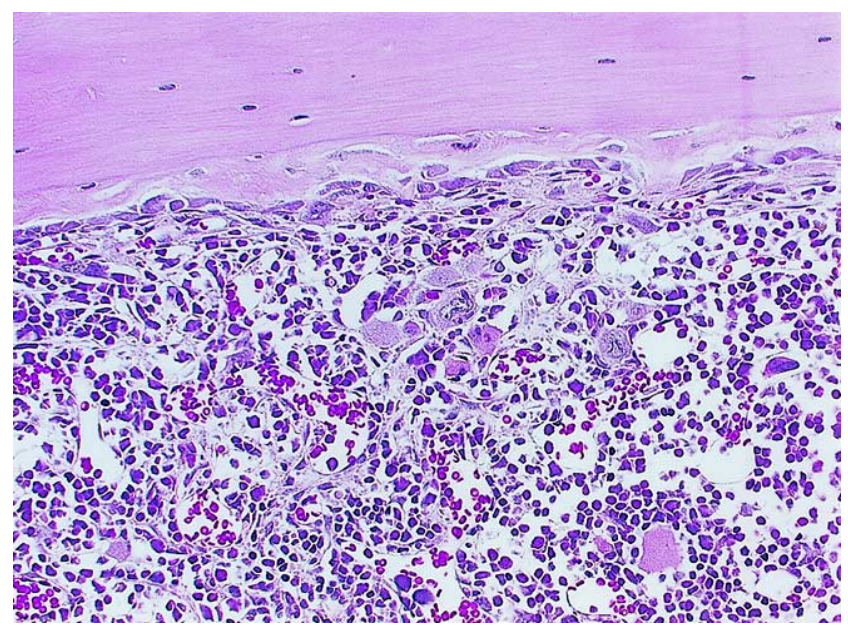

$\mathbf{E}$

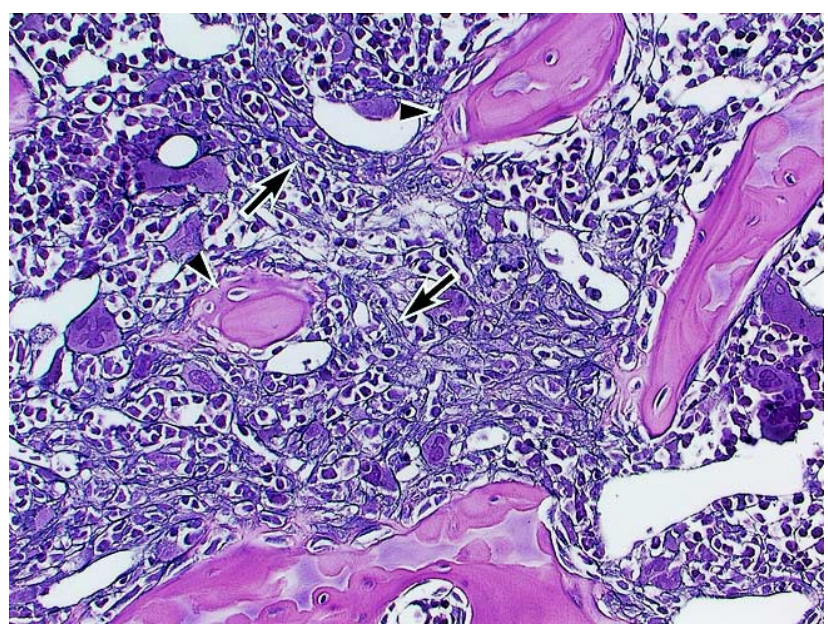

$\mathbf{F}$

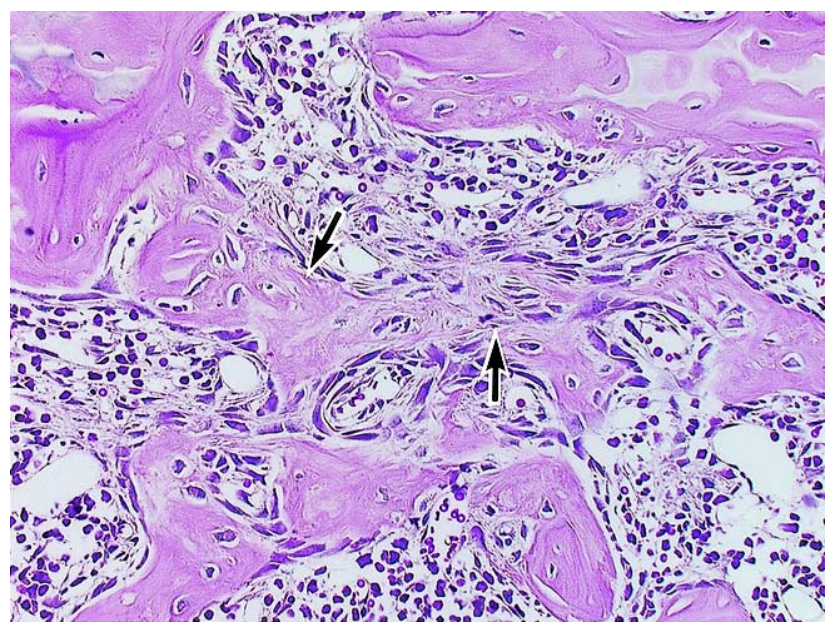

Fig. 3. Histological changes of the bone marrow of non-treated mice (A) or PEG-rHuMGDF-treated mice (B-F). An increase of reticulin fibers (arrows) and megakaryocyte hyperplasia are observed on day $9(\mathrm{~B}, \mathrm{C})$. Reticulin fibers are expanded between substantia (arrows), and partial osteoid formation is seen along substantia on day 11 (arrowheads) (D, E). New and excessive bone formation is seen on day 13 (arrows) (F). (C and E: Watanabe's silver stain) $\times 400$. 
Table 1. Histological Findings of Bone Marrow in Mice

\begin{tabular}{lccccc}
\hline & & \multicolumn{4}{c}{ PEG-rHuMGDF } \\
\cline { 3 - 6 } Findings & Non-treated & Day 9 & Day 11 & Day 13 & Day 15 \\
\hline \multirow{2}{*}{ Increase of reticulin fibers } & $0 / 5$ & $5 / 5( \pm: 5)$ & $5 / 5( \pm: 1,+: 4)$ & $0 / 5$ & $0 / 5$ \\
Osteiod formation & $0 / 5$ & $0 / 5$ & $5 / 5(+: 5)$ & $0 / 5$ & $0 / 5$ \\
Bone formation & $0 / 5$ & $0 / 5$ & $0 / 5$ & $4 / 5( \pm: 3,+: 1)$ & $3 / 5( \pm: 3)$ \\
\hline
\end{tabular}

Grades: $( \pm)$, very slight; (+), slight.

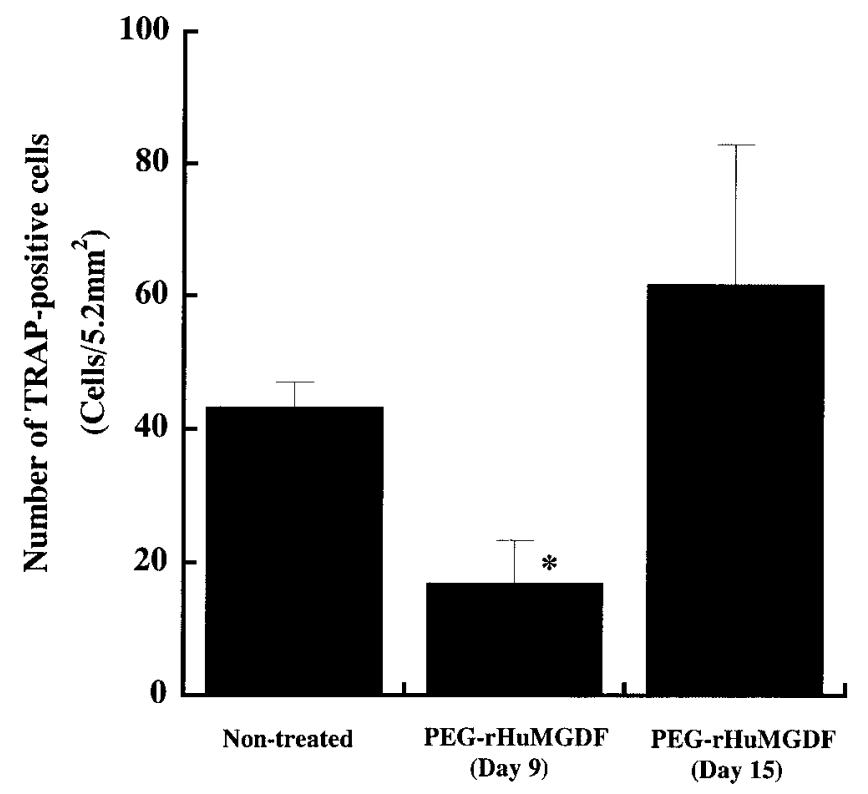

Fig. 4. Changes of the TRAP-positive cell numbers in the bone marrow. Each point represents the mean $\pm S D(n=5)$. Data were analyzed by the two-tailed Student's $t$-test. * $\mathrm{P}<0.05$ compared with vehicle-treated.

producing reticulin fibers did not express OPN mRNA or BGP mRNA. On day 11, at the stage involving reticulin fiber increase and osteoid formation, the cells producing reticulin fibers and forming osteoid expressed OPN mRNA, but not BGP mRNA. Osteoblasts around the trabeculae expressed OPN mRNA and BGP mRNA on day 11. On day 15 , the cells of newly and excessively formed bone expressed both OPN mRNA and BGP mRNA (Fig. 5).

\section{Discussion}

The suprapharmacological dose of PEG-rHuMGDF caused myelofibrosis and osteogenesis in mouse bone marrow in the present study, and the following results were obtained in PEG-rHuMGDF-treated mice: 1) The number of osteoclasts decreased, 2) expression of OPN mRNA in the cells producing reticulin fibers and forming osteoid was induced earlier than that of BGP mRNA in the bone marrow during the course of osteogenesis, particularly on day 11 , and 3 ) the TGF- $\beta 1$ level in the platelet-poor plasma of PEGrHuMGDF-treated mice was higher than that of vehicletreated mice.

In the present study, a decrease in osteoclast counts was observed concurrent with an increase of TGF- $\beta 1$ level in the PPP and megakaryocyte hyperplasia on day 9 in PEGrHuMGDF-treated mice. PEG-rHuMGDF is reported to inhibit osteoclastogenesis in vitro through the induction of TGF- $\beta 1^{23}$. PEG-rHuMGDF is also known to increase TGF$\beta 1$ levels derived from megakaryocytes in the bone marrow. Therefore, the decrease of osteoclast counts in PEGrHuMGDF-treated mice may be based on an increase of TGF- $\beta 1$ levels induced by megakaryopoiesis. The mechanism of bone resorption is considered that osteoclasts increase to remove excessive bone induced by PEGrHuMGDF in accordance with decrease of TGF- $\beta 1$ levels.

There is growing evidence to suggest that the genes commonly associated with defining the osteoblastic phenotype, such as the gene for type I collagen, osteocalcin, osteopontin, and alkaline phosphatase, may be expressed in a specific developmental sequence ${ }^{28}$. It is known that in skull formation of rats, the mRNAs for collagen, OPN, and BGP are expressed in that order, and that the differentiation markers appear in the order of collagen, OPN, and BGP during the differentiation from preosteoblasts to osteoblasts $^{29}$. In the present study, the expression of OPN mRNA was observed earlier than that of BGP mRNA, particularly on day 11 , suggesting that preosteoblasts or undifferentiated mesenchymal cells differentiated to form bone. Because several in vivo studies have demonstrated that TGF- $\beta 1$ promotes the proliferation of periosteal osteoblast precursor cells and formation of new woven bone $e^{22,30-33}$, undifferentiated mesenchymal cells or preosteoblasts in the bone marrow might be induced to differentiate into osteoblasts by the increased level of TGF$\beta 1$ derived from megakaryocytes in the bone marrow.

In our previous study of rats, PEG-rHuMGDF caused the increases of the TGF- $\beta 1$ level in the PPP, bone marrow fluid, and whole-bone extracts ${ }^{5}$. Since similar results were observed in PPP in the present study, it is probable that an increase of TGF- $\beta 1$ level also occurred in the bone marrow of the PEG-rHuMGDF-treated mice. We focused TGF- $\beta 1$ on PEG-rHuMGDF-inducing bone formation. Only TGF$\beta 1$ but also several factors regulate the development of 
A

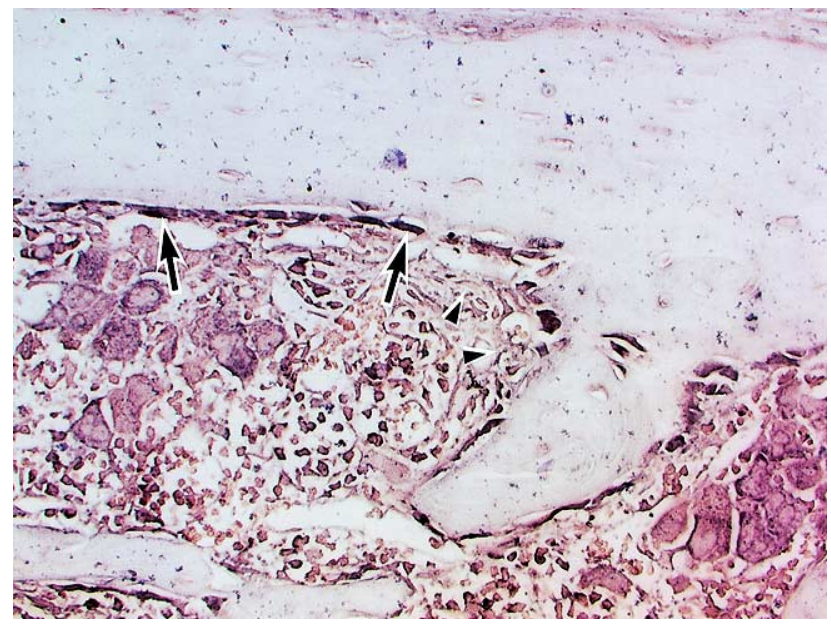

B

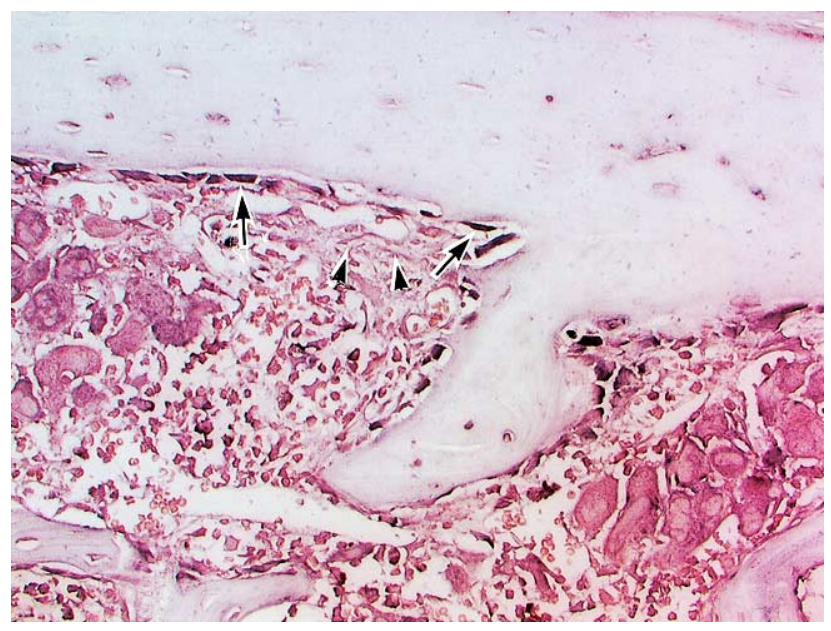

$\mathrm{C}$

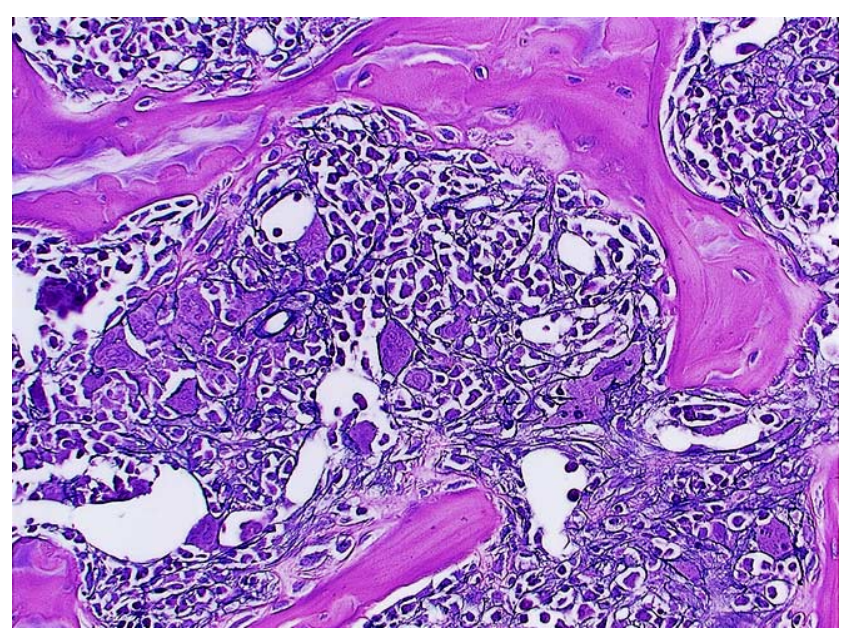

D

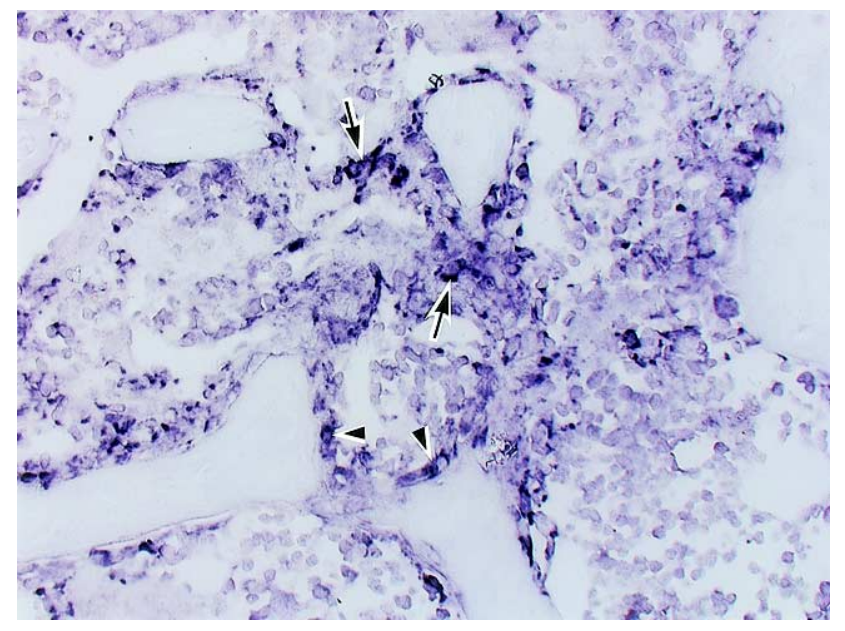

$\mathrm{E}$

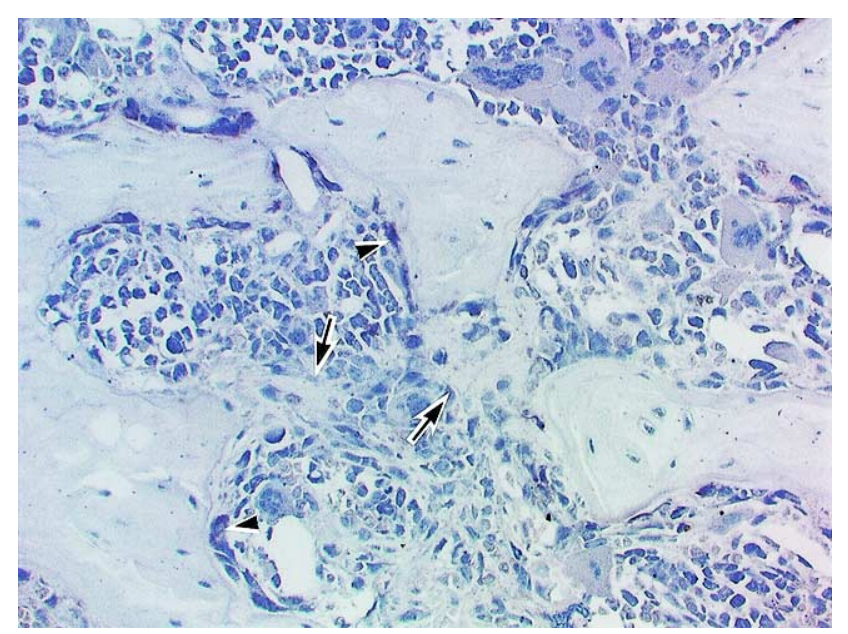

Fig. 5. In situ hybridization analysis of the OPN and BGP mRNA expression using digoxigenin-11-UTP-labeled single-stranded RNA probes. Osteoblasts at the endosteum express OPN mRNA (arrows) (A) and BGP mRNA (arrows) (B), whereas the cells involved in producing reticulin fibers do not express OPN mRNA or BGP mRNA (arrowheads). On day 11, the cells producing reticulin fibers and forming osteoid express OPN mRNA (arrows) (D), but not BGP mRNA (arrows) (E), whereas osteoblasts around the trabeculae express OPN mRNA and BGP mRNA (arrowheads). (C: Watanabe's silver stain preparation on day 11) $\times 400$. 
myelofibrosis and osteogenesis. Especially, PDGF and platelet factor 4 (PF4) which are located in alpha-granules of megakaryocytes, are hypothesized to be responsible for the pathogenesis of idiopathic myelofibrosis ${ }^{19-21}$. PDGF is an effective mitogen for fibroblasts ${ }^{34-35}$, whereas PF4 inhibits collagenase activity ${ }^{36}$. We preliminarily examined PDGF$A B$ levels in the PPP by using ELISA kit in this study, but the increase of PDGF-AB levels was not seen against our expectation (data not shown).

Although the effective dose of PEG-rHuMGDF in mice is similar to that of rats (about $1.0 \mu \mathrm{g} / \mathrm{kg}$ ) ${ }^{5,11}$, bone formation is seen at higher doses on mice $(1.0 \mathrm{mg} / \mathrm{kg})$ compared with rats $(0.1 \mathrm{mg} / \mathrm{kg})^{8}$. Similarly, PEG-rHuMGDF causes higher elevation of TGF- $\beta 1$ levels in rats than in mice ${ }^{5}$. It is probable that there is a difference between rats and mice in TGF- $\beta 1$ levels that megakaryocyte contains in alphagranules.

In conclusion, it is probable that PEG-rHuMGDF induced osteogenesis and inhibited osteoclastogenesis via elevated level of TGF- $\beta 1$ in the bone marrow. Therefore, PEG-rHuMGDF caused bone formation by changing the rate between bone resorption and bone formation.

Acknowledgements: The authors are grateful to Takeshi Ohshima and Takeyoshi Yamashita for their helpful technical advice.

\section{References}

1. Bartley TD, Bogenberger J, Hunt P, Li YS, Lu HS, Martin F, Chang MS, Samai B, Nichol L, Swift S, Johnson MJ, Hsu RY, Parker VP, Suggs S, Skrine JD, Merewether LA, Clogston C, Hsu E, Hokom MM, Hornkohl A, Choi E, Pangelinan M, Sun Y, Mar V, McNinch J, Simonet L, Jacobsen F, Xie C, Shutter J, Chute H, Basu R, Selander L, Trollinger D, Sieu L, Padilla D, Trail G, Elliott G, Izumi R, Covey T, Crouse J, Garcia A, Xu W, Del Castillo J, Biron J, Cole S, Hu MC-T, Pacifici R, Ponting I, Saris C, Wen D, Yung YP, Lin H, and Bosselman RA. Identification and cloning of a megakaryocyte growth and development factor that is a ligand for the cytokine receptor Mpl. Cell 1994; 77: $1117-1124$.

2. Lok S, Kaushansky K, Holly R, Kuijper JL, Lofton-Day CE, Oort PJ, Grant FJ, Heipel MD, Burkhead SK, Kramer JM, Bell LA, Sprecher CA, Blumberg H, Johnson R, Prunkard D, Ching AFT, Mathewes SL, Bailey MC, Forstrom JW, Buddle MM, Osborn SG, Evans SJ, Sheppard PO, Presnell SR, O'Hara PJ, Hagen FS, Roth GJ, and Foster DC. Cloning and expression of murine thrombopoietin cDNA and stimulation of platelet production in vivo. Nature 1994; 369: 565-568.

3. de Sauvage FJ, Hass PE, Spencer SD, Malloy BE, Gurney AL, Spencer SA, Darbonne WC, Henzel WJ, Wong SC, Kuang WJ, Oles KJ, Hultgren B, Solberg Jr LA, Goeddel DV, and Eaton DL. Stimulation of megakaryocytopoiesis and thrombopoiesis by the c-Mpl ligand. Nature 1994; 369: 533-538.

4. Kato T, Ogami K, Shimada Y, Iwamatsu A, Sohma Y, Akahori H, Horie K, Kokubo A, Kudo Y, Maeda E,
Kobayashi K, Ohashi H, Ozawa T, Inoue H, Kawamura K, and Miyazaki H. Purification and characterization of thrombopoietin. J Biochem 1995; 118: 229-236.

5. Yanagida M, Ide $Y$, Imai A, Toriyama M, Aoki T, Harada K, Izumi $\mathrm{H}$, Uzumaki $\mathrm{H}$, Kusaka $\mathrm{M}$, and Tokiwa $\mathrm{T}$. The role of transforming growth factor- $\beta$ in PEG-rHuMGDF-induced reversible myelofibrosis in rats. Br J Haematol 1997; 99: 739-745.

6. Farese AM, Hunt $\mathrm{P}$, Boone $\mathrm{T}$, and MacVittie TJ. Recombinant human megakaryocyte growth and development factor stimulates thrombocytopoiesis in normal nonhuman primates. Blood 1995; 86: 54-59.

7. Harker LA, Marzec UM, Hunt P, Kelly AB, Tomer A, Cheung E, Hanson SR, and Stead RB. Dose-response effects of pegylated human megakaryocyte growth and development factor on platelet production and function in nonhuman primates. Blood 1996; 88: 511-521.

8. Ide Y, Harada K, Imai A, and Yanagida M. PEG-rHuMGDF ameliorates thrombocytopenia in carboplatin-treated rats without inducing myelofibrosis. Int J Hematol 1999; 70: 9196.

9. Harker LA, Marzec UM, Kelly AB, Cheung E, Tomer A, Nichol JL, Hanson SR, and Stead RB. Prevention of thrombocytopenia and neutropenia in a nonhuman primate model of marrow suppressive chemotherapy by combining pegylated recombinant human megakaryocyte growth and development factor and recombinant human granulocyte colony-stimulating factor. Blood 1997; 89: 155-165.

10. Akahori H, Shibuya K, Obuchi M, Nishizawa Y, Tsuji A, Kabaya K, Kusaka M, Ohashi H, Tsumura H, Kato T, and Miyazaki H. Effect of recombinant human thrombopoietin in nonhuman primates with chemotherapy-induced thrombocytopenia. Br J Haematol 1996; 94: 722-728.

11. Ulich TR, del Castillo J, Yin S, Swift S, Padilla D, Senaldi G, Bennett L, Shutter J, Bogenberger J, Sun D, Samal B, Shimamoto G, Lee R Steinbrink R, Boone T, Sheridan WT, and Hunt P. Megakaryocyte growth and development factor ameliorates carboplatin-induced thrombocytopenia in mice. Blood 1995; 86: 971-976.

12. Akahori H, Shibuya K, Ozai M, Ida M, Kabaya K, Kato T, and Miyazaki H. Effects of pegylated recombinant human megakaryocyte growth and development factor on thrombocytopenia induced by a new myelosuppressive chemotherapy regimen in mice. Stem cells 1995; 14: 678689.

13. Yan X-Q, Lacey D, Hill D, Chen Y, Fletcher F, Hawley RG, and Mcniece IK. A model of myelofibrosis and osteosclerosis in mice induced by overexpressing thrombopoietin (mpl ligand): reversal of disease by bone marrow transplantation. Blood 1996; 88: 402-409.

14. Frey BM, Rafii S, Teterson M, Eaton D, Crystal RG, and Moore MAS. Adenovector-mediated expression of human thrombopoietin cDNA in immune-compromised mice: Insights into the pathophysiology of osteomyelofibrosis. J Immunology 1998; 160: 691-699.

15. Villeval JL, Cohen-Solal K, Tulliez M, Giraudier S, Guichard J, Burstein SA, Cramer EM, Vainchenker W, and Wendling F. High thrombopoietin production by hematopoietic cells induces a fatal myeloproliferative syndrome in mice. Blood 1997; 90: 4369-4383.

16. Friedenstein AJ, Latzinik NW, Grosheva AG, and Gorskaya UF. Marrow microenvironment transfer by heterotopic 
transplantation of freshly isolated and cultured cells in porous sponges. Exp Haematol 1982; 12: 217-227.

17. Beresford JN. Osteogenic stem cells and the stromal system of bone and marrow. Clin Orthop Rel Res 1989; 240: 270280.

18. Owen M. Marrow stromal stem cells. J Cell Sci 1988; 10: 63-76.

19. Bernabei PA, Arcangeli A, Casini M, Grossi A, Paddvani R, and Rossi P. Platelet-derived growth factor (s) mitogenic activity in patients with myeloproliferative disease. Br J Haematol 1986; 63: 353-357.

20. Castro-Malaspina H. Pathogenesis of Myelofibrosis: Role of ineffective megakaryopoiesis and megakaryocyte components. New York: Alan R. Liss, 1984.

21. McCarthy DM. Fibrosis of the bone marrow: content and causes. Br J Haematol 1985; 59: 1-7.

22. Noda M, and Camilliere JJ. In vivo stimulation of bone formation by transforming growth factor-beta. Endocrinology 1989; 124: 2291-2294.

23. Wakikawa $T$, Shioi A, Hino M, Inaba M, Nishizawa $Y$, Tatsumi N, Morii H, and Otani S. Thrombopoietin inhibits in vitro osteoclastogenesis from murine bone marrow cells. Endocrinology 1997; 138: 4160-4166.

24. Castro-Malaspina H, Rabellino EM, Yen A, Nachman RL, and Moore MAS. Human megakaryocyte stimulation of proliferation of bone marrow fibroblasts. Blood 1981; 57: 781-787.

25. Baglin TP, Price SM, and Boughton BJ. A reversible defect of platelet PDGF content in myeloproliferative disorders. Br J Haematol 1988; 69: 483-486.

26. Pecquet S, Pfeifer A, Gauldie S, and Fritsche R. Immunoglobulin E suppression and cytokine modulation in mice orally tolerized to $\beta$-lactoglobulin. Immunology 1999 ; 96: $278-285$.

27. Nakase T, Takaoka K, Hirakawa K, Hirota S, Takemura T, Onoue H, Takebayashi K, Kitamura Y, and Nomura S.
Alterations in the expression of osteonectin, osteopontin and osteocalcin mRNAs during the development of skeletal tissue in vivo. Bone Miner 1994; 26: 109-122.

28. Yoon K, Buenaga R, and Rodan GA. Tissue specificity and developmental expression of rat osteopontin. Biochem Biophy Res Comm 1987; 148: 1129-1136.

29. Owen T, Aronow M, Shalhoub V, Barone LM, Wilming L, Tassinari MS, Kennedy MB, Pockwinse S, Lian JB, and Stein GS. Progressive development of the rat osteoblast phenotype in vitro: Reciprocal relationships in expression of genes associated with osteoblast proliferation and differentiation during formation of the bone extracellular matrix. J Cell Physiol 1990; 143: 420-430.

30. Joyce ME, Roberts $\mathrm{AB}$, Sporn MB, and Bolander ME. Transforming growth factor- $\beta$ and the initiation of chondrogenesis and osteogenesis in the rat femur. J Cell Biology 1990; 110: 2195-2207.

31. Beck LS, Amento EP, Xu Y, Deguzman L, Lee WP, Nguyen $\mathrm{T}$, and Gillett NA. TGF-beta 1 induces bone closure of skull defects. J Bone Min Res 1991; 6: 1257-1265.

32. Beck LS, Deguzman L, Lee WP, Xu Y, McFatridge LA, Gillett NA, and Amento EP. TGF- $\beta 1$ induces bone closure of skull defects: temporal dynamics of bone formation in defects exposed to rhTGF- $\beta 1$. J Bone Min Res $1993 ; 8$ : $753-$ 761.

33. Marcelli C, Yates AJ, and Mundy GR. In vivo effects of human recombinant transforming growth factor $\beta$ on bone turnover in normal mice. J Bone Min Res 1990; 5: 10871096.

34. Ross R, Raines EW, and Bowen-pope DF. The biology of platelet-derived growth factor. Cell 1986; 46: 155-169.

35. Heldin CH. Structural and functional studies on plateletderived growth factor. EMBO J 1992; 11: 4251-4259.

36. Hiti-Harper J, Wohl H, and Harper E. Platelet factor 4: an inhibitor of collagenase. Science 1978; 199: 4251-4259. 